\title{
Evaluation of the Performance of some Evapotranspiration Models at a Tropical Location in Ile - Ife, Nigeria
}

Adekunle B. Toyeje ${ }^{1}$, Lukman A. Sunmonu ${ }^{1}$, Ayodele P. Olufemi2 ${ }^{*}$, Oladimeji A. Babatunde ${ }^{1}$, Olawale E. Abiye $^{3}$, Olanrewaju O. Soneye-Arogundade ${ }^{1}$, Muritala A. Ayoola ${ }^{1}$, Opeyemi R. Omokungbe ${ }^{1}$, Omodara E. Obisesan $^{1}$

\author{
${ }^{1}$ Department of Physics and Engineering Physics, Obafemi Awolowo University \\ Ile-Ife, Nigeria \\ ${ }^{2}$ Department of Physics, University of Medical Sciences \\ Ondo, Ondo State, Nigeria \\ ${ }^{3}$ Centre for Energy Research and Development (CERD), Obafemi Awolowo University \\ Ile-Ife, Nigeria \\ *Corresponding authore-mail: aolufemi [AT] unimed.edu.ng
}

\begin{abstract}
This study evaluates the performance of some evapotranspiration models at Ile - Ife $\left(7^{\circ} 33^{\prime} \mathrm{N}, 4^{\circ} 33^{\prime}\right.$, E) Nigeria. This was to identify suitable evapotranspiration (ET) models at the study site and to provide useful information for standardizing evapotranspiration estimations at a tropical location. Meteorological parameters (wind speed, relative humidity, temperature, solar radiation, soil heat flux, and net radiation) were routinely measured at the Obafemi Awolowo University (OAU) Meteorological Station located within the Teaching and Research Farm of the campus for a period of a month (1st - 29th July 2014). Nine standardized models for the estimation of ET; PenmanMonteith (FAO-56 PM), Priestly-Taylor (PT), Makkink(MAKK), Jensen-Haise (JH), Hargreaves-Samani (HS), Ivanov (IVA), Modified Romanenko (MROM), FAO-24 Radiation (FAO-24 RAD) and Turc (TURC) models were employed. The ET values obtained from these models were then compared to the estimated values obtained from the FAO-56PM equation recommended as the international standard method for determining reference ET. The estimation of the ET obtained from FAO-56 PMmodel ranged between 0.426-2.239 mm/day, MAKK, JH, and HS gave estimation closest to this, ranging from $0.544-2.272 \mathrm{~mm} /$ day. The estimation of ET from other models revealed that $P$ Thas the highest value ranging between $1.323-6.936 \mathrm{~mm} /$ day, followed closely was $F A O-24 R A D$ with values ranging between 1.197 - $6.500 \mathrm{~mm} /$ day, values of IVA model ranged from 0.620 - $1.829 \mathrm{~mm} /$ day, MROM value ranged from 1.240 - 3.659 $\mathrm{mm} /$ day, TURC has the least value ranging from $0.190-0.584 \mathrm{~mm} /$ day. Using the result of the mean biased errorand regression analysis, JH model compared best with the FAO - 56 PM with coefficient of determination $(R 2)=0.927$; slope $(b)=0.957$; mean biased error $(\mathrm{MBE})=0.133$, this was followed closely by $\mathrm{HS}$ with value $\mathrm{R} 2=0.929 ; \mathrm{b}=1.199$; $M B E=-0.075$ and $M A K K$ with the value $R 2=0.931 ; b=1.198 ; M B E=-0.052$. However, the other models showed significant over or underestimation of the ET benchmark values. The performance of the other models showed no improvement after they were recalibrated by adjusting their original coefficients. Thus, six out of the ET models employed in this study [the Priestly-Taylor (PT), Makkink (MAKK), Jensen-Haise (JH), Hargreaves-Samani (HS), FAO-24 Radiation (FAO-24 RAD) and Turc (TURC)] were found suitable for the climatic region of Ile -Ife after the adjustment of their coefficients.
\end{abstract}

Keywords---- Evapotranspiration, Peaman-Monteith, Hagreaves-Samani, Makkink, Turc, FAO-24 Radiation

\section{INTRODUCTION}

Evapotranspiration (ET) is a crucial parameter for monitoring the transfer of mass, momentum, and energy between the soil-vegetation-atmosphere interface. The quantification of the Evapotranspiration parameters is important for climatological and agro-meteorological purposes (Hasen et al., 1980; Abdelkrimet al., 2014). The direct measurement techniques of ET are reportedly costly and tedious for long-termdeployment (Fontenot, 2004; Smith et al., 1991; Allen et al., 1998; Ogolo, 2014). Researchers have resorted to estimating this parameter fromempirical relationships that depend on routinely measured surface layer weather parameters. Hill et al. (1983) reported more than fifty methods or variations available for estimation of Evapotranspiration. These methods can be broadly classified as (a) temperature-based, (b) radiation based, and (c) combined method comprising of both temperature and radiation parameter in its mathematical expression (Jensen et al., 1990; Dingman, 1994; Watson and Burnett 1995; Drexler et al., 2004). The combined method accommodates vapourization dynamics, aerodynamic characteristics, and other surface layer flow properties in its formulation. This allows for robust and accurateET estimates irrespective of the climatic regime. Therefore, as a generally 
accepted variant of the combined method, the FAO-56 Penman-Monteith equation is recommended as the international standard method for determining reference ET (Jensen et al., 1990; Allen et al., 1998; Allen et al., 2011; Irmak et al., 2008; Hargreaves and Allen, 2003). Based on the foregoing, studies have established that ET estimates obtained from the Penman-Monteith equation have s trong correlations with directly measured ET values under different climatic conditions (Xu and Singh, 2002; Oudin et al., 2005; Egwuonwu et al., 2011). However, because of the expansive framework of the FAO-56 PM equation requiring numerous input data, there is the need to evaluate the performances of other ET es timation methods that require fewer input parameters for regions like Nigeria with data paucity.

In a recent study carried out in Ile-Ife, the FAO-56 PM method compared favorably with the direct measurement of ET obtained from the Eddy Covariance technique (Babatunde et al., 2017). Although the study demonstrated the veracity of the FAO-56 PM method as an accurate ET determining technique in the absence of direct measurements, it is limited in terms of the number of models requiring fewer input parameters evaluated. In this present study, eight ET models requining fewer input parameters will be evaluated based on the estimates obtained fromFAO-56 PM.

\section{Site Description and Ins trumentation}

\section{METHODOLOGY}

Figure 1 shows the location of Ile-Ife $\left(7.52^{\circ} \mathrm{N}, 4.52^{\circ} \mathrm{E}\right)$ Nigeria, at the "tropical wet and dry" zone of West Africa according to Köppen 's classification (Griffiths, 1974). Average annual precipitation ranges from 1000 to $1500 \mathrm{~mm}$, and the surface wind is typically weak, $u<1.5 \mathrm{~ms}^{-1}$ (Hayward and Oguntoyinbo, 1987; Jegede, 1998; Jegede, et al., 2006). Due to its proximity to the equator, the intensity of s olar radiation received at Ile-Ife's surface is high all year round. From the hourty global radiation data at Ile-Ife, maxima are found at about 13:00 LT, with values of 1100 and $800 \mathrm{Wm}^{-2}$ for $\mathrm{March}$ and August, res pectively (Balogun et al., 2003).

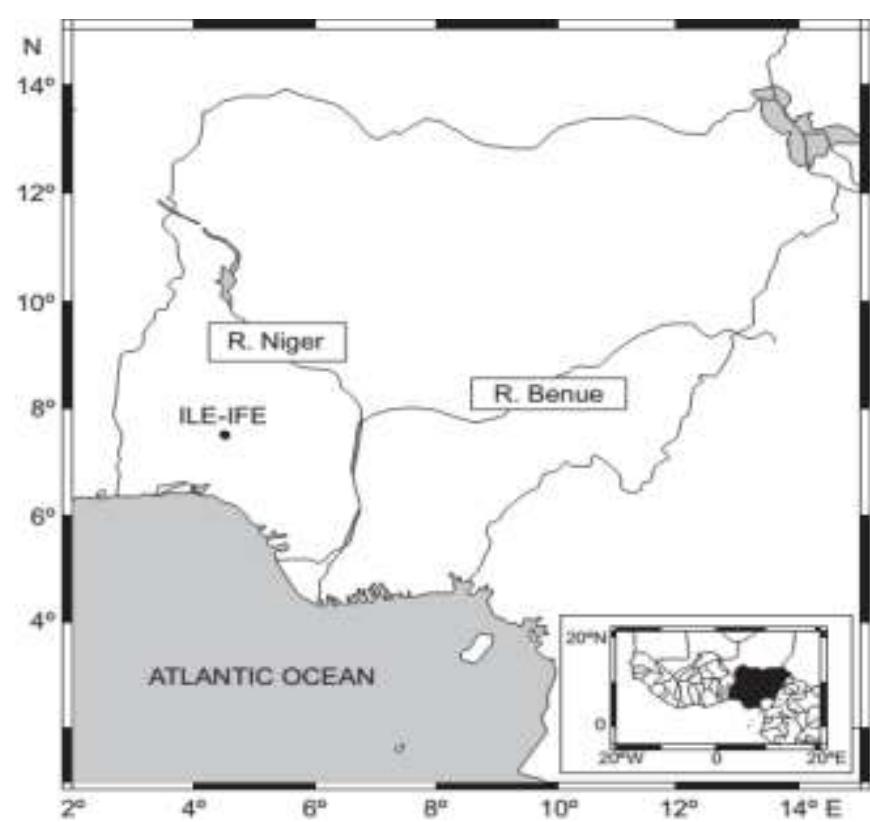

Fig. 1. Outline map of Nigeria showing the location oflleIfe $\left(7.52^{\circ} \mathrm{N}, 4.52^{\circ} \mathrm{E}\right)$, where the routine measurement parameter was recorded. Insert is the sub-continent of West Africa.

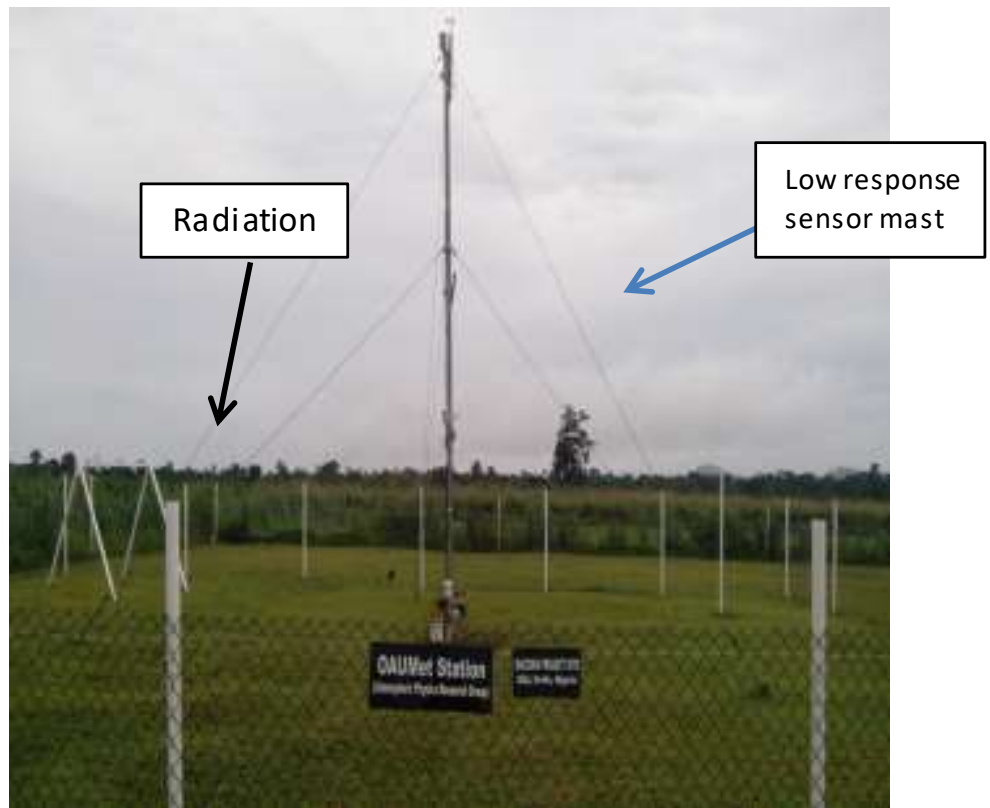

Fig 2: OAU Meteorological Station located within Teaching and Research Farm, OAU Campus, Ile - Ife.

A time series of the basic meteorological parameters such as netradiation, ground heat flux, air temperature, humidity, soil heat flux, vapor pressure, atmospheric pressure, among others were sampled every $10 \mathrm{~s}$ and stored at every minute. The measurement site had dimensions approximating $50 \mathrm{~m}$ by $60 \mathrm{~m}$ and its surface was covered by short grass which was mowed regularly throughout the measurement period to maintain its evenness. In the middle of the measurement enclosure, a $6 \mathrm{~m}$ mast with booms hanging meteorological sensors such as cup anemometer, temperature, and humidity sensor was positioned at two levels $(0.3 \mathrm{~m}$ and $2 \mathrm{~m})$ for gradient measurement of wind speed, air temperature, and relative humidity. Also, on another $1.7 \mathrm{~m}$ high radiation stand, a REBS net radiometer (NR-LITE) was positioned (Fig. 2). Heat flux plates were buried in the ground at depths of $2 \mathrm{~cm}, 10 \mathrm{~cm}$, and $30 \mathrm{~cm}$, with the one at the topmost used in this study. 
Data acquisition of these meteorological variables was programmed using the LOGGERNET® software supplied by Campbell Scientific, s ampled at 10s intervals, and stored as 1-min. averages, using a Campbell Scientific datalogger, model CR1000. Acquisition of data at the site started in June 2014 and it is continuous but for the purpose of this study, the period between 1st and 29th July 2014 was used. Data for the period were subsequently and carefully checked for instrumental errors while a stringent QA/QC procedure was introduced to remove spurious data and replace mis sing values.

A standardized dataanalysis software package was used for the analysis of the variations of the measured parameters.

\section{EVAPOTRANSPIRATION MODELS EMPLOYED IN THE STUDY}

The theoretical framework of the eight (8) ET models requiring les s input parameters which were evaluated in this study together with that of the benchmark method, the Penman-Monteith $(F A O-56 P M)$ model are presented in Table 1

Table 1: The Evapotranspiration Models used in this Study

\begin{tabular}{|l|l|c|}
\hline Models & Reference(s) & Formulations \\
\hline FAO-56PM & Qui et.al., (2002) & $E T_{P M}=\frac{0.408 \Delta\left(R_{n}-G\right)+\frac{\gamma 670 U_{z}\left(e_{S}-e_{a}\right)}{\Delta+\gamma\left(1+0.602 U_{z}\right)}}{\Delta+273}$ \\
\hline FAO24 Radiation & Doorenbos and Pruitt (1977) & $\mathrm{ET}_{\mathrm{FAO} 24}=a+b\left[\frac{\Delta}{\Delta+\gamma}\right] R_{s}$ \\
\hline Turc & Turc (1961) & $E T_{T U R C}=a_{T} 0.013 \frac{T_{m}}{T_{m}+15} \times \frac{23.9 R_{s}+50}{\lambda}$ \\
\hline Makkink & Makkink(1957) & $E T_{M A K K}=0.61 \frac{\Delta}{\Delta+\gamma} \frac{R_{s}}{2.45}-0.12$ \\
\hline Jensen-Haise & Rosenberg et al. (1983) & $E T_{J H}=\frac{R_{S}}{2.45} \times\left[\left(0.025 \times T_{m}\right)+0.08\right]$ \\
\hline Priestly-Taylor & Priestley and Taylor(1972) & $E T_{P T}=\alpha \frac{\Delta}{\Delta+\gamma}\left(R_{n}-G\right)$ \\
\hline Hargreaves-Samani & $\begin{array}{l}\text { Hargreaves and Samani (1985) } \\
\text { Hargreaves and Allen (2003) }\end{array}$ & $\mathrm{ET}_{H S}=0.0135 \times R_{s} \times 0.4082 \times\left(T_{m}+17.8\right)$ \\
\hline Ivanov & Romanenko (1961) & $\mathrm{ET}_{\mathrm{IVA}}=0.000036 \times\left(25+T_{m}\right)^{2} \times(100$ \\
\hline Modified Romanenko & Oudin et al. (2005) & $E T_{m R O M}=4.5\left[1+\left(\frac{T_{m}}{25}\right)\right]^{2}\left[1-\frac{e_{a}}{e_{s}}\right]$ \\
\hline
\end{tabular}

where $E T_{P M}$ is the evapotranspiration $\left(\mathrm{mm}_{\mathrm{day}}{ }^{-1}\right)$ using the FAO-56PM model, $R_{n}$ is net radiation $\left(\mathrm{Wm}^{-2}\right), \mathrm{G}$ is soil heat flux $\left(W m^{-2}\right), \gamma$ is the psychrometric constant $\left(=0.000665 \mathrm{kPa}^{\circ} \mathrm{C}^{-1}\right), e_{s}$ is the saturation vapour pressure $(\mathrm{kPa})$, $e_{a}$ is the actual vapour pressure $(k P a), \Delta$ is the slope of the saturation vapour pressure-temperature curve $\left(k P a^{\circ} C^{-1}\right), T_{m}$ -mean daily air temperature, $R H_{m}$ - daily mean relative humidity, $R_{s}$ is solar radiation, $\alpha(=1.26)$

Moreover, fromthe ET estimates that were obtained fromthe model equations, a regression analysis based on least square techniques was used to adjust (recalibrate) the original coefficients involved in their formulation. This es sentially will provide an adjusted constant that will enhance the suitability of the models for ET estimation under tropical conditions such as the study area. Hence, in this study, the selected ET models, FAO 24, TURC, MAKK, JH, PT, HS, IVA, and $M R O M$, were recalibrated using the reference, $F A O$ - 56 PM. Thus, the intercept, a, and slope, b, of the line of best fit obtained between the benchmark method and other models were used as site-dependent modification coefficients equation (1) (Tabari et al., 2011; Houshang et.al., 2012):

$E T_{P M}=b\left(E T_{\text {model }}\right)+a$

To quantitatively examine the performance of the model equations before and after their coefficients were adjusted, error es timates and some statistical indices were calculated Table 2

Table 2: Performance Evaluation of the SelectedModels

\begin{tabular}{|l|c|}
\hline Statistcal Indices & Expression \\
\hline Mean Bias Error & $\mathrm{MBE}=\mathrm{N}^{-1} \sum_{i=1}^{N}\left(P_{i}-O_{i}\right)$ \\
\hline Root Mean Square Error & $\mathrm{RMSE}=\left[\mathrm{N}^{-1} \sum_{i=1}^{N}\left(P_{i}-O_{i}\right)^{2}\right]^{0.5}$ \\
\hline Index of Agreement & $d=1-\frac{\sum_{i=1}^{N}\left(P_{i}-O_{i}\right)^{2}}{\sum_{i=1}^{N}[/ \mathrm{Pi}-\overline{\mathrm{O}} /+/ \mathrm{O}-\overline{\mathrm{O}} /]^{2}}$ \\
\hline
\end{tabular}




\section{RESULTS AND DISCUSSION}

The daily mean values of evapotranspiration, ET estimates obtained from the study carried out are presented in Table 3. The values in $\mathrm{mm} /$ day es timated, ranges from 0.43 to $2.24 ; 1.92$ to $6.50 ; 0.19$ to $0.58 ; 0.59$ to $1.75 ; 0.65$ to $2.21 ; 1.32$ to 6.94; 0.54 to 1.76 ; 0.62 to 1.83 and 1.24 to 3.66 for FAO-56 PM, FAO-24 RAD, TURC, MAKK, JH, PT, HS, IVA and MROM models res pectively for the period of study (July 2014). The results obtained are pres ented graphically in Figure 3. The figure displayed the diurnal variation of ET es timates obtained from the models at the study site. From the graph, the values obtained from the models showed a similar pattern of flu ctuations over the diurnal course. As shown in the Figures, during the nocturnal periods and early morning before sunrise (at about 19:00LT to about 09:00LT), significant evapotranspiration does not occur. The ET values obtained at these periods are nearly zero. This is as a result of the fact that there is no sufficient available energy from sunlight and wind to drive the process significantly at such times under stable/neutral atmospheric boundary layer conditions. During the daytime, however, as the surface becomes sufficiently warm and uns tably stratified, the rate of ET occurrence gradually rises until it reaches peak values around the solar noon (13:00LT). From the result pres ented in both Table 3 and Figure 3, es timated values of ET given by JH model are closest to those of FAO-56 PM chosen as benchmark method. Meanwhile, the estimates are given by PT and FAO-24 RAD significantly overestimated the reference ET values by more than $100 \%$ while TURC, MAKK, IVA, and HS underestimated the reference values.

Table 3 showing the daily values of ET estimate obtained from the methods

\begin{tabular}{|c|c|c|c|c|c|c|c|c|c|c|}
\hline $\begin{array}{l}\text { DAT } \\
\text { E } \\
\text { JUL } \\
\text { Y,20 } \\
\text { 14 }\end{array}$ & $\begin{array}{l}\text { DO } \\
\text { Y }\end{array}$ & $\begin{array}{l}\text { PM } \\
(\mathbf{m m} / \mathbf{d a} \\
\mathbf{y})\end{array}$ & $\begin{array}{l}\text { FAO 24 } \\
\text { (mm/day } \\
\text { ) }\end{array}$ & 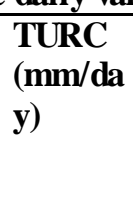 & $\begin{array}{l}\begin{array}{l}\text { MAKK } \\
\text { (mm/da } \\
\text { y) }\end{array} \\
\end{array}$ & $\begin{array}{l}\text { JH } \\
(\mathbf{m m} / \mathbf{d a} \\
\mathbf{y})\end{array}$ & $\begin{array}{l}\text { PT } \\
(\mathbf{m m} / \mathbf{d a} \\
\mathbf{y})\end{array}$ & $\begin{array}{l}\text { HS } \\
(\mathbf{m m} / \mathbf{d a} \\
\mathbf{y})\end{array}$ & 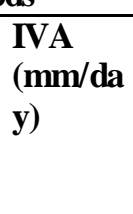 & $\begin{array}{l}\text { MROM } \\
(\mathbf{m m} / \mathbf{d a} \\
\text { y) }\end{array}$ \\
\hline $1^{\text {st }}$ & 182 & 1.67 & 5.26 & 0.47 & 1.40 & 1.79 & 5.18 & 1.42 & 1.37 & 2.74 \\
\hline $2^{\text {nd }}$ & 183 & 2.24 & 6.27 & 0.58 & 1.75 & 2.21 & 6.94 & 1.76 & 1.67 & 3.33 \\
\hline $3^{\text {rd }}$ & 184 & 1.37 & 4.29 & 0.41 & 1.21 & 1.51 & 4.23 & 1.21 & 1.36 & 2.72 \\
\hline $4^{\text {th }}$ & 185 & 1.68 & 4.29 & 0.40 & 1.23 & 1.46 & 5.19 & 1.19 & 1.35 & 2.70 \\
\hline $5^{\text {th }}$ & 186 & 1.90 & 5.84 & $\overline{0.51}$ & 1.55 & 1.88 & 5.91 & 1.52 & 1.46 & 2.93 \\
\hline $6^{\text {th }}$ & 187 & 1.97 & 6.50 & 0.55 & 1.67 & 2.06 & 6.11 & 1.66 & 1.81 & 3.62 \\
\hline $7^{\text {th }}$ & 188 & 0.86 & 3.14 & 0.29 & 0.90 & 1.03 & 2.68 & 0.85 & 0.89 & 1.78 \\
\hline $8^{\text {th }}$ & 189 & 1.10 & 3.26 & 0.30 & 0.93 & 1.08 & 3.40 & 0.89 & 1.24 & 2.47 \\
\hline $9^{\text {th }}$ & 190 & 1.17 & 3.79 & 0.34 & 1.04 & 1.23 & 3.62 & 1.00 & 1.39 & 2.77 \\
\hline $10^{\text {th }}$ & 191 & 1.49 & 4.78 & 0.46 & 1.39 & 1.71 & 4.60 & 1.37 & 1.63 & 3.26 \\
\hline $11^{\text {th }}$ & 192 & 1.60 & 5.37 & 0.49 & 1.47 & 1.85 & 4.97 & 1.48 & 1.77 & 3.55 \\
\hline $12^{\text {th }}$ & 193 & 1.72 & 5.87 & 0.53 & 1.57 & 1.99 & 5.33 & 1.58 & 1.83 & 3.66 \\
\hline $13^{\text {th }}$ & 194 & 0.69 & 2.68 & 0.27 & 0.82 & 0.95 & 2.14 & 0.78 & 0.99 & 1.97 \\
\hline $14^{\text {th }}$ & 195 & 1.82 & 5.72 & 0.53 & 1.58 & 2.01 & 5.63 & 1.60 & 1.72 & 3.44 \\
\hline $15^{\text {th }}$ & 196 & 1.55 & 4.91 & 0.46 & 1.36 & 1.74 & 4.80 & 1.38 & 1.60 & 3.20 \\
\hline $16^{\text {th }}$ & 197 & 0.90 & 2.87 & 0.28 & 0.86 & 0.97 & 2.78 & 0.80 & 1.04 & 2.08 \\
\hline $17^{\text {th }}$ & 198 & 0.43 & 1.92 & 0.19 & 0.59 & 0.65 & 1.32 & 0.54 & 0.62 & 1.24 \\
\hline $18^{\text {th }}$ & 199 & 1.46 & 5.14 & 0.44 & 1.34 & 1.62 & 4.55 & 1.31 & 1.40 & 2.81 \\
\hline $19^{\text {th }}$ & 200 & 1.63 & 5.07 & 0.44 & 1.34 & 1.62 & 5.06 & 1.31 & 1.49 & 2.97 \\
\hline $20^{\text {th }}$ & 201 & 1.57 & 4.95 & 0.45 & 1.34 & 1.66 & 4.87 & 1.34 & 1.44 & 2.87 \\
\hline $21^{\mathrm{st}}$ & 202 & 0.92 & 3.43 & 0.32 & 0.97 & 1.16 & 2.86 & 0.94 & 1.07 & 2.15 \\
\hline $22^{\text {nd }}$ & 203 & 0.92 & 2.75 & 0.25 & 0.76 & 0.89 & 2.85 & 0.73 & 1.05 & 2.10 \\
\hline $23^{\text {rd }}$ & 204 & 1.49 & 2.82 & 0.25 & 0.76 & 0.90 & 4.62 & 0.74 & 1.40 & 2.80 \\
\hline $24^{\text {th }}$ & 205 & 0.69 & 2.52 & 0.25 & 0.75 & 0.87 & 2.15 & 0.72 & 1.03 & 2.07 \\
\hline $25^{\text {th }}$ & 206 & 0.80 & 2.80 & 0.26 & 0.80 & 0.93 & 2.50 & 0.76 & 1.00 & 2.00 \\
\hline $26^{\text {th }}$ & 207 & 0.97 & 3.16 & 0.30 & 0.92 & 1.10 & 3.01 & 0.89 & 1.11 & 2.22 \\
\hline $27^{\text {th }}$ & 208 & 1.93 & 5.11 & 0.48 & 1.42 & 1.79 & 5.98 & 1.43 & 1.45 & 2.89 \\
\hline $28^{\text {th }}$ & 209 & 1.53 & 4.13 & 0.40 & 1.21 & 1.44 & 4.74 & 1.17 & 1.04 & 2.09 \\
\hline $29^{\text {th }}$ & 210 & 1.14 & 3.30 & 0.32 & 0.96 & 1.15 & 3.52 & 0.93 & 1.22 & 2.44 \\
\hline
\end{tabular}

The performances of the ET models employed in the study were remarkably improved by adjusting their original coefficient using a simple technique based on regression analysis carried out between each model and the reference method (FAO-56 PM) and the results are presented in Figure 4. The coefficients obtained from the regression analysis carried out were used as new empirical constants to adjust the ET model equations as presented in Table 4. The impact of this adjustment was then examined on an unused four days' dataset, the results before and after coefficient adjustment were presented in Figure 
5 , it can be observed that model results improved after the coefficient adjustment as the gaps between the models and the reference method closed up. To quantify this improvement some statistical indicators namely $M B E, R S M E$, $d$, and slope $(b)$ were calculated and presented in Table 5. From this table, error values reduced significantly, the index of agreement increased and the slope was near unity after the coefficien ts of the original model equations were adjusted.
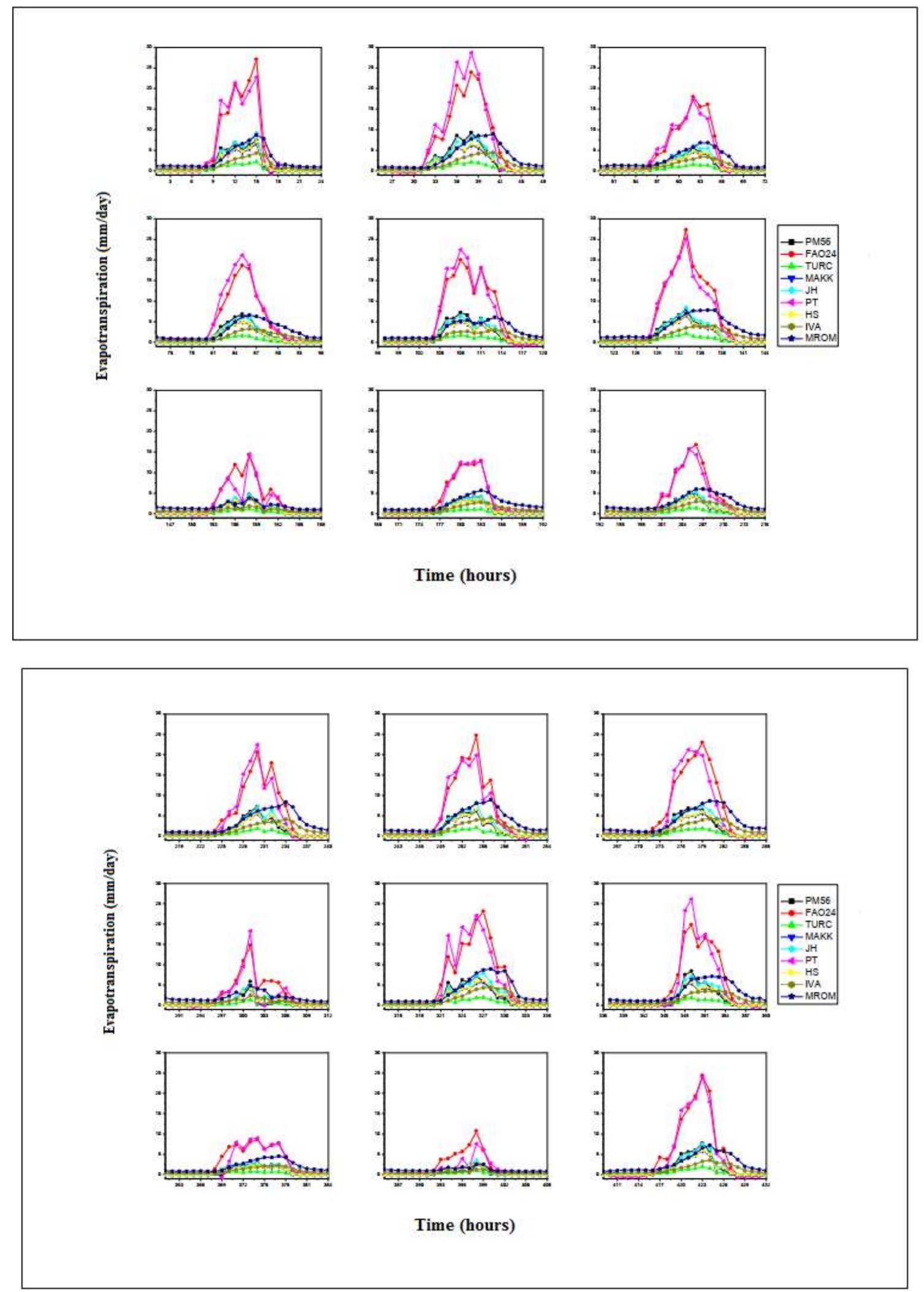

Fig. 3: Diurnal Variation of ET Estimation obtained from Nine Selected Models for (a): 25 ${ }^{\text {th }}$ July 2014 (DOY 206); (b): $26^{\text {th }}$ July 2014 (DOY 207); (c): $27^{\text {th }}$ July 2014 (DOY 208); (d): $28^{\text {th }}$ July 2014 (DOY 209); and (e): $29^{\text {th }}$ July 2014 (DOY 210). 

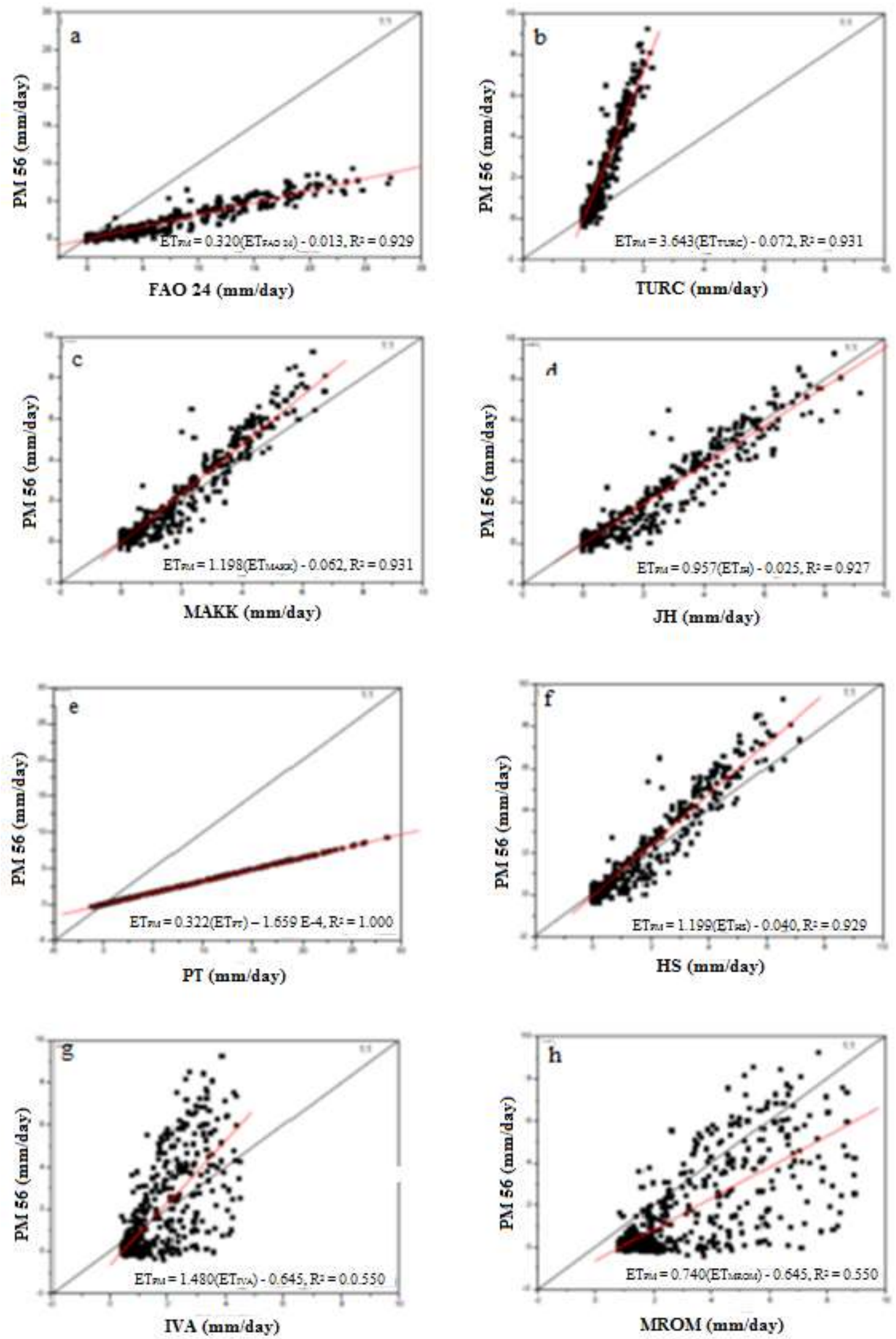

Figure 4: FAO-56 PM Model Es timated ET Values against Empirical Methods [( $a$ ): FAO 24 Radiation (FAO 24 RAD); (b): Turc (TURC); (c): Makkink $(M A K K)$; (d): Jensen Haise $(J H)$; (e): Priestley-Taylor $(P T)$; $(f)$ : Harg reavesSamani $(H S)$; $(g)$ : Ivanov $(I V A)$; and $(h)$ : Modified Romanenko $(M R O M)$ ] es timated values using the original constant values involved in each equation 

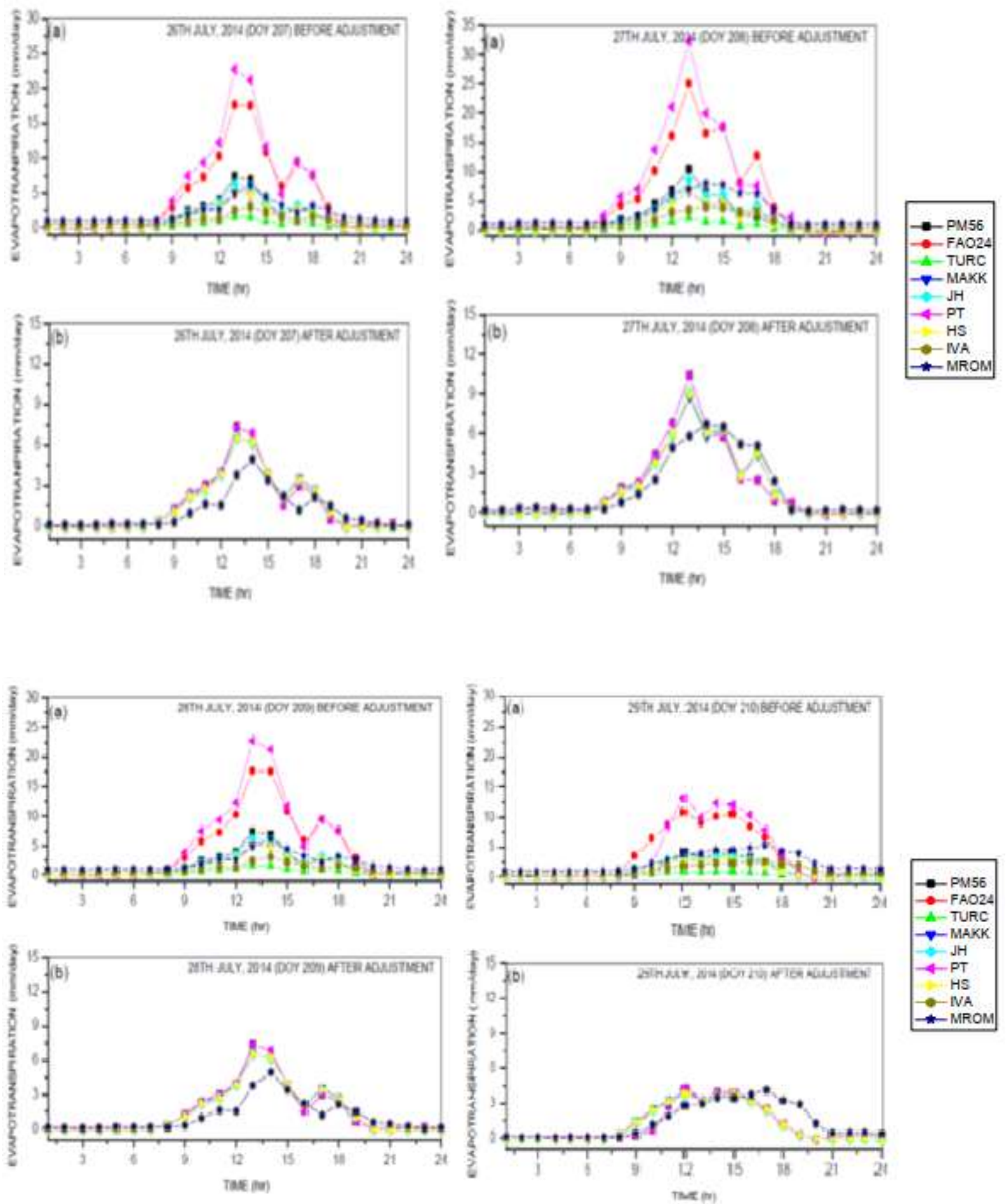

Figure 5: Plot of ET Estimated by the FAO-56 PM Method and Eight Empirical Methods with (a): Original constant and (b): Recalibrated constant values involved in each equation for $26^{\text {th }} 27$ th $28^{\text {th }} 29^{\text {th }}$ July, 2014 
Table 4: The Result of the Calibration Coefficient obtained from the Regression Analysis for Models Adjus tment

\begin{tabular}{|c|l|}
\hline Original Models & Adjusted Models \\
\hline $\mathrm{ET}_{\mathrm{FAO} 24}=a+b\left[\frac{\Delta}{\Delta+\gamma}\right] R_{s}$ & $-0.013+0.320\left(a+b\left[\frac{\Delta}{\Delta+\gamma}\right] R_{s}\right)$ \\
\hline$E T_{\text {TURC }}=0.013 T_{a} * \frac{23.9 R_{s}+50}{T_{a}+15}$ & $-0.072+3.643\left(0.013 T_{a} * \frac{23.9 R_{S}+50}{T_{a}+15}\right)$ \\
\hline$E T_{M A K K}=0.61 \frac{\Delta}{\Delta+\gamma} * \frac{R_{s}}{\lambda}-0.12$ & $-0.062+1.198\left(0.61 \frac{\Delta}{\Delta+\gamma} * \frac{R_{S}}{\lambda}-0.12\right)$ \\
\hline$E T_{J H}=\frac{R_{S}}{2.45} *\left[\left(0.025 * T_{m}\right)+0.08\right]$ & $0.025+0.957\left(\frac{R_{S}}{2.45} *\left[\left(0.025 * T_{m}\right)+0.08\right]\right)$ \\
\hline$E T_{P T}=1.26 \frac{\Delta}{\Delta+\gamma}\left(R_{n}-G\right)$ & $1.659 \mathrm{E}-4+0.322\left(1.26 \frac{\Delta}{\Delta+\gamma}\left(R_{n}-G\right)\right)$ \\
\hline $\mathrm{ET}_{H S}=0.0135 * R_{S} * C o n c\left(T_{m}+17.8\right)$ & $-0.040+1.199\left(0.0135 * R_{S} * C o n c\left(T_{m}+17.8\right)\right)$ \\
\hline $\mathrm{ET}_{\mathrm{IVA}}=0.00003 *\left[\left(25+T^{2}\right)\right.$ & $-0.645+1.480\left(0.00003 *\left[\left(25+T^{2}\right) *(100+\right.\right.$ \\
$* E T_{M R O M}=4.5\left[1+\left(\frac{T_{m}}{25}\right)\right]^{2}\left[1-\frac{e_{a}}{e_{s}}\right]$ & $-0.645+0.740\left(4.5\left[1+\left(\frac{T_{m}}{25}\right)\right]^{2}\left[1-\frac{e_{a}}{e_{s}}\right]\right)$ \\
\hline
\end{tabular}


Table 5: Statistical Analysis of ET Models before and after Recalibration

Before and after Recalibration

\begin{tabular}{|c|c|c|c|c|c|c|c|c|}
\hline \multicolumn{9}{|c|}{ 26th July, 2014 (DOY207) } \\
\hline MODELS & MBE & $\mathrm{MBE}_{\mathrm{a}}$ & RMSE & $\overline{\text { RMSE }_{\mathrm{a}}}$ & D & $d_{a}$ & Slope (b) & Slope $_{a}\left(b_{a}\right)$ \\
\hline FAO 24 & 2.194 & 0.143 & 2.360 & 0.345 & 0.6511 & 0.005 & 0.307 & 0.843 \\
\hline TURC & -0.666 & 0.146 & 0.695 & 0.379 & $-6.9 \mathrm{E}-05$ & 0.108 & 3.277 & 0.826 \\
\hline MAKK & -0.052 & 0.150 & 0.353 & 0.397 & 0.980 & 0.283 & 1.060 & 0.816 \\
\hline JH & 0.133 & 0.142 & 0.325 & 0.357 & 0.960 & -0.619 & 0.885 & 0.843 \\
\hline PT & 2.037 & 0.001 & 2.037 & 0.001 & 0.808 & 0.093 & 0.322 & 0.999 \\
\hline HS & -0.075 & 0.144 & 0.329 & 0.370 & 0.953 & 0.245 & 1.092 & 0.833 \\
\hline IVAN & 0.140 & 0.241 & 0.704 & 0.539 & 0.820 & 0.891 & 1.441 & 0.756 \\
\hline MROM & 1.250 & 0.241 & 1.253 & 0.539 & 0.413 & -0.052 & 0.721 & 0.756 \\
\hline \multicolumn{9}{|c|}{ 27th July, 2014 (DOY208) } \\
\hline MODELS & MBE & $\mathrm{MBE}_{\mathrm{a}}$ & RMSE & $\mathbf{R M S E}_{\mathbf{a}}$ & D & $d_{a}$ & Slope (b) & Slope $_{a}\left(b_{a}\right)$ \\
\hline FAO 24 & 3.180 & -0.110 & 3.286 & 0.428 & 0.000 & 0.032 & 0.373 & 1.026 \\
\hline TURC & -1.455 & -0.134 & 1.482 & 0.396 & 0.232 & 0.018 & 4.136 & 1.043 \\
\hline MAKK & -0.508 & -0.156 & 0.626 & 0.393 & 0.786 & 0.067 & 1.377 & 1.060 \\
\hline JH & -0.143 & -0.100 & 0.411 & 0.401 & 0.979 & -1.360 & 1.070 & 1.019 \\
\hline PT & 4.050 & 0.001 & 4.102 & 0.001 & 0.000 & -0.027 & 0.323 & 1.000 \\
\hline HS & -0.502 & -0.115 & 0.625 & 0.398 & 0.808 & 0.065 & 1.351 & 1.032 \\
\hline IVAN & -0.484 & -0.078 & 1.183 & 0.879 & 0.750 & -1.423 & 1.939 & 1.017 \\
\hline MROM & 0.963 & -0.078 & 1.383 & 0.879 & 0.000 & 0.056 & 0.969 & 1.017 \\
\hline \multicolumn{9}{|c|}{ 28th July, 2014 (DOY209) } \\
\hline MODELS & MBE & $\mathrm{MBE}_{\mathrm{a}}$ & RMSE & $\mathbf{R M S E}_{\mathbf{a}}$ & D & $d_{a}$ & Slope (b) & Slope $_{a}\left(b_{a}\right)$ \\
\hline FAO 24 & 2.601 & -0.063 & 2.639 & 0.224 & 0.000 & -0.052 & 0.385 & 1.057 \\
\hline TURC & -1.132 & -0.047 & 1.147 & 0.210 & 0.075 & 0.058 & 4.145 & 1.045 \\
\hline MAKK & -0.321 & -0.032 & 0.377 & 0.216 & 0.552 & 0.286 & 1.346 & 1.036 \\
\hline JH & -0.092 & -0.067 & 0.218 & 0.209 & 0.833 & 1.000 & 1.113 & 1.060 \\
\hline$\overline{\mathrm{PT}}$ & 3.208 & 0.002 & 3.234 & 0.002 & 0.000 & -0.071 & 0.323 & 0.999 \\
\hline $\mathrm{HS}$ & -0.359 & -0.055 & 0.407 & 0.209 & 0.447 & 2.645 & 1.378 & 1.052 \\
\hline IVAN & -0.484 & -0.443 & 1.122 & 0.753 & 0.000 & 0.436 & 2.789 & 1.463 \\
\hline MROM & 0.560 & -0.443 & 1.072 & 0.753 & 0.784 & -0.002 & 1.394 & 1.463 \\
\hline \multicolumn{9}{|c|}{ 29th July, 2014 (DOY210) } \\
\hline MODELS & MBE & $\mathrm{MBE}_{\mathrm{a}}$ & RMSE & $\mathbf{R M S E}_{\mathrm{a}}$ & D & $d_{a}$ & Slope (b) & Slope $_{a}\left(b_{a}\right)$ \\
\hline FAO24 & 2.158 & 0.024 & 2.245 & 0.256 & 0.601 & 0.066 & 0.353 & 0.970 \\
\hline TURC & -0.819 & 0.066 & 0.849 & 0.285 & $-5.6 \mathrm{E}-05$ & -1.295 & 3.777 & 0.952 \\
\hline MAKK & -0.174 & 0.041 & 0.399 & 0.300 & 0.000 & 0.093 & 1.215 & 0.953 \\
\hline $\mathrm{JH}$ & 0.010 & 0.022 & 0.273 & 0.267 & 1.000 & -2.348 & 1.029 & 0.980 \\
\hline PT & 2.387 & 0.001 & 2.414 & 0.002 & 0.637 & 0.072 & 0.322 & 0.998 \\
\hline HS & -0.204 & 0.028 & 0.408 & 0.276 & 0.000 & 0.082 & 1.263 & 0.964 \\
\hline IVAN & 0.083 & 0.282 & 0.829 & 0.573 & 0.000 & 0.827 & 1.689 & 0.886 \\
\hline MROM & 1.302 & 0.282 & 1.331 & 0.573 & 0.000 & -0.057 & 0.845 & 0.886 \\
\hline
\end{tabular}

NOTE: $M B E_{a}, R_{M S E}, d_{a}$, Slope $_{a}$ are adjusted values

\section{CONCLUSION}

Based on the findings of the study, JH model has a strong agreement with FAO-56 PM and can be adjudged suitable for ETestimation at tropical locations such as Ile-Ife, Nigeria.

Also, PT, FAO-24 RAD, TURC, MAKK, HS, and IVA models are considered suitable for tropical conditions only after their original constants are empirically adjusted. This information will be useful for irrigation schedulers, drought predictors, and agro-meteorologists. 


\section{REFERENCES}

Abdelkrim, K., Abdelkader, K., and Abderrahmane, H. (2014): Using the Pries tley-Taylor expression for es timating actual evapotranspiration from satellite Landsat ETM + data. Evolving Water Resources Systems: Understanding, Predicting and Managing Water-Society Interactions Proceedings of ICWRS2014, Bologna, Italy, IAHS Publ. 364.

Allen, R. G., Pereira, L.S., Reas D., Smith M. (1998): Crop evapotranspiration guidelines for computing requirements. Food and Agric Org anization (FAO) Irrig ation and Drainage paper 56, Rome, 326.

Allen, R.G., Pereira, L.S., Howell, T.A., and Jensen, M.E. (2011): Evapotranspiration information reporting 1: Factors governing measurement accuracy. Agricultural Water Management, 98(6):899-920.

Balogun, A.A., Jegede, O.O., Olaleye, J.O., (2003). Surface radiation budget over bare so il at Ile-Ife, Nigeria. Niger. J. Sol. Energy 14, 6-13.

Babatunde O.A. Abiye O.ESunmonu L.A., Olufemi A.P., Ayoola M.A. Akinola O.E, Ogolo E.O (2017): A Comparative evaluation of four evapotranspiration models based on Eddy Covariance measurement over a grass covered surface in Ile - Ife, Southwestern Nigeria. ModelEarth Syst. Environ.

Dingman, S.L. (1994): Physical Hydrology. Upper Saddle River, NJ: Prentice Hall

Doorenbos, J. and Pruitt. W.O. (1977): Guidelines for predicting crop water requirements. FAO Irrigation and Drainage Paper 24. Food and Agriculture Org anization. Rome

Drexler, J.Z., Bedford, B.L., DeGaetano, A. and Siegel, D.I., (2004): Quantification of the water budget and nutrient loading for a small peatland in central New York. Journal of the American Water Research Association 34: 753 769.

Egwuon wu C.C., Okafor V.C., Ezeany a N.C., Nzediegwu C. and Okorafor O.O. (2011): A comparison of the reliability of six Evapotranspiration computing models for Abeokuta in South western Nigeria. Greener Journal of physical sciences 2(4):064-069.

Fontenot, R.L.B.S. (2004): an evaluation of reference evapotranspiration models in Louisiana State University and A\&M College.

Griffiths, J.F., (1974): World Survey of Climatology, in: J.F. Griffiths (Ed.), Climates of Africa 10, Elsevier, Amsterdam, 620.

Hay ward, D.F. and Oguntoyinbo, J.S., (1987): The climatology of West Africa, Rowan and Littlefield, New York (1987), 271.

Hansen, V.E., Israelsen, O.W., and StringhamG.E. (1980): Irrigation principles and practic es $4^{\text {th }}$ edition. New York, NY: John Wiley and sons inc.

Hargreaves, G. H. and Allen, R. G. (2003): History and evaluation of Harg reaves evapotranspiration equation. Journal of Irrigation and Drainage Engineering,129(1),53-63.

Hargreaves, G. H. and Samani, Z. A. (1985). Reference crop evapotranspiration fromtemperature. Applied Engineering in Agriculture, 1(2), 96.

Hill R. W., Johns, E. L. and Frevert. D. K. (1983). Comparison of equations u sed for estimating agricultural crop evapotranspiration with field research. Bureau of Reclamation, U. S. Dep. Of the Interior Eng. and Res. Ctr., Denver, Colo. 26 (12) 2937-2944

Houshang G., Vahid R., Erfan K., Hos sein M., (2012): Time and place calibration of the Hargreaves equation for estimating monthly reference evapotranspiration under different climatic conditions. Journal of Agricultural Science, 4, 3 .

Irmak, S., Irmak, A., Howell, T.A., Martin, D.L., Payero, J.O., and Copeland K.S. (2008): Variability analy ses of alfalfareference to grass-reference evapotranspiration ratios in growing dormant seasons. J. Irrig. Drain eng., ASCE, 134 (2), 147-159. 
Jegege O.O., (1998): A field study of the mean surfacelayer structure in sub-Saharan West Africa the Pre-monsoon (dry) season Mausam, 48 (1998), 361-370.

Jegede O.O., Ogolo E.O. and Aregbesola, T.O., (2006): Estimating net radiation using routine meteorological data at a tropical location in Nigeria. International Journal of Sus tainable Energy, 25(2), 107-115.

Jensen, M. E., Burman, R. D., Allen, R. G., (1990): Evapotranspiration and irrigation water requirements Committee on Irrig ation Water Requirements. American Society of CivilEngineers a manual, New York.

Makkink, G.F., (1957): Testing the Penman Formu la by means of ly simeters. Journal of the institution of water engineering 11(3):277-288.

Ogolo E.O., (2014): The comparative analysis of performance evaluation of recalibrated reference evapotranspiration models for different regional climatic conditions in Nigeria. Ife Journalof Science (16): 2

Oudin, L.; Hervieu, F.; Michel, C.; Perrin, C.; Andreassian, V.; Anctil, F. \& Loumagne, C. (2005). Which Potential Evapotranspiration Input for a Lumped Rainfall-Runoff Model? Part 2 - Towards a Simple and Efficient PotentialEvapotranspiration Modelfor Rainfall-Runoff Modelling. Journal of Hydrology, 303, 290-306.

Priestly, C.H.B., and Taylor, R.J. (1972): On the assessment of surface heat flux and evaporation using large- scale parameters. Monthly weather review 100(2):81-92.

Qiu, G.Y., Miyamoto, K., Sase, S., Gao, Y., Shi, P. and Yano, T. (2002): Comparis on of the Three Temperaturemodel and conventional models for estimating transpiration. Japanese Agricultural Research Quarterly 36(2):73-82

Romanenko, V.A. (1961) Computation of the autumn soil moisture using a universal relationship for a large area. Proceeding, Ukrainian Hydro Meteorological Res earch Institute, 3.

Rosenberg, N.J., Blad, B.L, Verma, S.B. (1983): Microclimate the Biolog ical Environment, 2nd Edition, John Wiley \& Sons, New York.

Smith, M., Allen, R.G., Monteith, J.L., Pereira, L.S., Perrier, A., and Pruitt, W.O. (1991): Report on the expert consultation on procedures for revision of FAO guidelines for prediction of crop water requirements. Land and Water Development Division, United Nations Food and Agriculture Service: Rome

Tabari, H., Grimser, M. and Trajkovic, S. (2011): Comparative analy sis of 31 reference evapotranspiration methods under humid conditions. Irrig. Sci., 31 (2), 107-117.

Turc, L. (1961). Estimation of irrigation water requirements, potential evapotranspiration: A simple climatic formula evolved up to date. Annals of Agronomy. (12), 13-14.

Watson, I. and Burnett, A.D. (1995). Hydrology: An en vironmental approach. Boca Raton, FL: CRC Press.

Xu, C.-Y. and Singh, V. P. (2002). Cross comparison of empirical equations for calculating potential evapotranspiration with data from Switzerland. Water Res ources Management, 16, 197-219. 